\title{
Krzysztof Plata
}

(Kraków)

\section{PRÓBA OCENY EFEKTYWNOŚCI POLITYKI ZAGRANICZNEJ I BEZPIECZEŃSTWA UNII EUROPEJSKIEJ}

\begin{abstract}
This paper aims to demonstrate the ineptitude of the European Union in implementing action to ensure security of the member states and, in consequence, pursuing effective foreign policy towards states which are indirectly involved in the relationships within the European region. The author argues the proposition through confrontation and interpretation of knowledge conveyed in expert sources.
\end{abstract}

\section{Key words}

Common Foreign and Security Policy, European Union, Joint Investigation Teams, EuroMaidan 
Polityka zagraniczna i bezpieczeństwa Unii Europejskiej (UE) w czasach współczesnych stoi przed wyzwaniem o ogromnym znaczeniu strategicznym dla rozwoju i funkcjonowania tej instytucji. Trwa wiele dyskusji na temat tego, czy polityka ta jest odpowiednio sformułowana, a także idąc dalej, czy funkcjonuje w sposób właściwy. Na podstawie obserwacji można zaryzykować stwierdzenie, że polityka zagraniczna jest nieudolna, zaś bezpieczeństwa nie istnieje. Warto zadać sobie pytanie, czy nie jest to jedynie niepoparte niczym zapewnianie ludzi, obywateli państw członkowskich i nie tylko, o ich bezpieczeństwie, dające swobodę działania w innych sferach polityki. Za tym stwierdzeniem $\mathrm{w}$ sposób dobitny przemawia niedawny konflikt zbrojny na wschodniej Ukrainie, czy też kryzys migracyjny, a także w jego konsekwencji zamachy terrorystyczne w państwach o dużym znaczeniu na arenie międzynarodowej.

Solidną podstawą do omawiania polityki zagranicznej i bezpieczeństwa jest Traktat o UE z Maastricht $\mathrm{z}$ dnia 7 lutego $1992 \mathrm{roku}^{1}$, gdzie określono pierwotne zasady funkcjonowania wszystkich sfer polityki UE. Jednakże warto zaznaczyć, że prowadzenie wspólnej polityki zagranicznej i bezpieczeństwa państw członkowskich nie jest równoznaczne z wprowadzeniem jednej polityki dla wszystkich tych krajów ${ }^{2}$. Jest to o tyle ważne, że owe założenia $\mathrm{w}$ tych sferach każdego $\mathrm{z}$ państw członkowskich muszą być regulowane w sposób uwzględniający interes narodowy, tzw. rację stanu, która w odpowiednim stopniu będzie zgodna $\mathrm{z}$ wymogami UE. W wyniku takiego rozumowania w Tytule V Traktatu o UE zapisano powstanie Wspólnej Polityki Zagranicznej i Bezpieczeństwa (WPZiB) ${ }^{3}$. Wojny w byłej Jugosławii i innych obszarach konfliktowych pokazały bezsilność UE w pewnych sferach polityki, dlatego też sformułowano dwa traktaty regulujące WPZiB. Pierwszym z nich był Traktat Amsterdamski, który zacieśniał współpracę wśród państw członkowskich Wspólnoty Europejskiej (WE)4 . Drugim zaś był Traktat Nicejski, który zastosował postanowienia Traktatu Amsterdamskiego do $\mathrm{WPZiB}^{5}$.

Niemniej ważny okazał się kolejny dokument, mianowicie Traktat Lizboński, który ostatecznie wszedł w życie z dniem 1 grudnia 2009 roku' . Równocześnie można stwierdzić, że dla postrzegania WPZiB był on przełomowy.

\footnotetext{
${ }^{1}$ Ciamaga i in. 2002, s. 16.

${ }^{2}$ Wijaszka 1995, s. 10.

${ }^{3}$ Willa 2012, s. 19.

${ }^{4}$ Turczyński 2007, s. 38.

${ }^{5}$ Ibidem, s. 40.

${ }^{6}$ Turczyński 2013, s. 93.
} 
Pierwszym z postanowień odnoszących się do tej sfery było skonsolidowanie kompetencji uprzednich stanowisk Wysokiego przedstawiciela ds. polityki zagranicznej i bezpieczeństwa i Komisarza ds. stosunków wewnętrznych na rzecz Wysokiego Przedstawiciela ${ }^{7}$. Jego zadaniem jest przede wszystkim pośredniczenie w prowadzeniu polityki zagranicznej i bezpieczeństwa pomiędzy Radą Europejską (RE) a Parlamentem, co przejawia się głównie na płaszczyźnie inicjowania wniosków i przekazywania najistotniejszych informacji ${ }^{8}$. Co więcej, automatycznie został on przewodniczącym Rady do Spraw Zagranicznych ${ }^{9}$. Jednakże jego najważniejszą rolą stało się reprezentowanie UE, a także prowadzenie ewentualnych rozmów ze stronami trzecimi w sprawach kompetencyjnych polityki zagranicznej i bezpieczeństwa ${ }^{10}$.

Mając na uwadze wszystkie postanowienia regulujące prowadzenie polityki zagranicznej, a także stosowanie określonych zasad bezpieczeństwa UE, można przeanalizować wydarzenia $\mathrm{w}$ Europie, przy których wspomniana płaszczyzna została zastosowana, a także zweryfikowana jako nieudolna. Pierwszym (pomijając konflikty na Bałkanach) z tych wydarzeń był kryzys migracyjny, który ogarnął większą część państw członkowskich UE. Z migracją łączy się pojęcie azylu, które jest ujmowane w różny sposób. Obserwacje sytuacji kryzysowej ukazują, że próby ujednolicenia polityki azylowej wśród krajów UE zakończyły się niepowodzeniem ${ }^{11}$. Problemem zatem staje się brak dostatecznej kontroli na granicach, a także ich wzmocnienia ${ }^{12}$. Doskonałym tego przykładem jest Republika Federalna Niemiec. Polityka socjalna i azylowa zakłada tam zapewnienie migrantom podstawowych praw w postaci zakwaterowania, a także minimum do przetrwania i opieki społecznej ${ }^{13}$. $\mathrm{Na}$ podstawie obserwacji niedawnych problemów z przyjmowaniem tzw. uchodźców można powiedzieć, że rząd niemiecki, nie mogąc poradzić sobie z napływem ludności na tak wielką skalę, rozsiał kryzys migracyjny na inne kraje UE. Można zatem stwierdzić, że polityka kanclerz Niemiec Angeli Merkel opierała się na artykule 78 Traktatu o Funkcjonowaniu UE (TFUE), mówiącym o prowadzeniu szeroko pojętej polityki azylowej, a także wspólnym przyjmowaniu uchodźców, bez względu na możliwości danego kraju człon-

\footnotetext{
${ }^{7}$ Boniecka 2015, s. 48

${ }^{8}$ Ibidem.

${ }^{9}$ Sekretariat Generalny Rady Unii Europejskiej 2009.

${ }^{10}$ Ibidem.

${ }^{11}$ O’Nions 2014.

${ }^{12}$ Huysmans 2006, , s. 69.

${ }^{13}$ Folkerts-Landau 2015, s. 15.
} 
kowskiego ${ }^{14}$. Spowodowało to niezadowolenie ze strony innych państw członkowskich, m.in. Francji, która musiała borykać się $\mathrm{z}$ atakami terrorystycznymi np. $\mathrm{z}$ dnia 13 listopada 2015 roku w stolicy ${ }^{15}$, a także Węgier, które pod wpływem wzrastającej liczby uchodźców zamknęły swoją granicę z Serbią, co stało się fenomenem na skalę światową ${ }^{16}$.

Kontynuując problematykę sytuacji Francji, trzeba wskazać w jak wysokim stopniu uzależnione jest bezpieczeństwo jednego $\mathrm{z}$ najważniejszych państw UE od całej wspólnoty. Brak reakcji ze strony państw UE lub też nieudolne próby ratowania sytuacji $\mathrm{w}$ postaci powołania planu relokacji migrantów między wszystkie państwa członkowskie ${ }^{17}$ wywołały problemy gospodarczo-społeczne w kraju. Ponadto kryzys implikował coraz poważniejsze konsekwencje, jakimi były już wcześniej wspomniane zamachy terrorystyczne, przy których UE nie miała pola manewru. Najważniejsza zatem staje się kwestia tego, jak w tak skrajnej sytuacji powinna zareagować UE. Mianowicie powinna zostać zastosowana polityka bezpośredniego przeciwdziałania terroryzmowi na terenie państw członkowskich, przy szczególnym uwzględnieniu problematyki różnic między tą polityką a kontrolą graniczną ${ }^{18}$. Jednakże nie można jednoznacznie zaprzeczyć temu, że obie te sfery polityki są ze sobą w pewnym stopniu powiązane. Powstał zatem pomysł utworzenia i wykorzystywania Joint Investigation Teams, które miały na celu identyfikowanie i ściganie przestępczości przygranicznej ${ }^{19}$. Był to jedynie niewielki krok ku przezwyciężeniu kryzysu, który przerodził się w nieoficjalną wojnę $\mathrm{z}$ radykalizmem islamskim. Jednakże nie postanowiono nic, co mogłoby dać szansę całkowitego zlikwidowania terroryzmu czy też samego kryzysu migracyjnego. Stosowano jedynie środki zastępcze, które miały upozorować działania mające na celu zlikwidowanie istoty problemu.

Problem Węgier pojawił się już na początku, gdy migranci zaczęli masowo przemieszczać się na zachód Europy, mając najkrótszą drogę przez właśnie ten kraj. Postawa rządu tego państwa była wyjątkowa w porównaniu do reszty państw członkowskich, gdyż wprost mówiono o niechęci do przyjmowania migrantów ${ }^{20}$. Komisja Europejska, a także The United Nations Refugee

\footnotetext{
${ }^{14}$ Krzyżanowski, s. 37-38.

${ }^{15}$ Keren 2015, s. 2.

${ }^{16}$ UNHCR The UN Refugee Agency 2016, s. 8

17 Potyrała 2014, s. 37.

${ }^{18}$ Bigo i in. 2015, s. 4

19 Ibidem, s. 5.

${ }^{20}$ Juhasz, Hunyadii Zgut 2015, s. 14.
} 
Agency (UNHCR) w pełni potępiły politykę antymigracyjną Węgier ${ }^{21}$. Wyciągając wnioski z obserwacji polityki migracyjnej Victora Orbana, można nawet stwierdzić, że postępował on niehumanitarnie względem przybywających migrantów, m.in. lokując ich w niehigienicznych warunkach w obozach ${ }^{22}$. Pokazuje to jedynie rozumianą szeroko wolność państw członkowskich do ustalania praw w ramach wspólnoty i bezsilność UE w jej ograniczeniu. Co więcej, nie wyciągnięto żadnych konsekwencji względem tego państwa, co powinno być naturalnym następstwem ukazującym sprzeciw wobec danych restrykcji.

Kolejnym wydarzeniem ukazującym nieudolność UE w sferze polityki zagranicznej i bezpieczeństwa była aneksja znajdującego się na południu Ukrainy Krymu przez Federację Rosyjską. Warto zatem po krótce przybliżyć historię relacji między Ukrainą a UE, a także zwrócić uwagę na trzeciego gracza, jakim była Federacja Rosyjska. Poczynając od proklamacji niepodległości 16 lipca 1990 roku, aż po wykorzystaną sytuację w Moskwie (pucz przeciw władzy) 24 sierpnia 1991 roku $^{23}$ Ukraina formalnie uwolniła się ze strefy wpływów Rosji. Dlatego też już po utworzeniu Wspólnoty Niepodległych Państw (WNP), gdzie Ukraina i Rosja miały różne wizje funkcjonowania, pojawiła się tzw. doktryna Pawłyczki. Zakładała ona pełną neutralność polityczną Ukrainy w każdej sferze, a także otwarcie się na zachód, wyłączając interakcję $\mathrm{w}$ formie sojuszu lub innych bezpośrednich form uzależnienia ${ }^{24}$. Uogólniając, można to uznać za pierwszą próbę zintegrowania się z Europą. Jednakże faktyczne konsultacje $\mathrm{w}$ tej sprawie rozpoczęto dopiero $\mathrm{w}$ marcu 1994 roku, zaś 14 czerwca 1994 roku podpisano Porozumienie o Partnerstwie i Współpracy $(\mathrm{PCA})^{25}$. Dalsze zacieśnianie więzi opierało się głównie o budowanie planów pomocy dla Ukrainy, które przewidywały przede wszystkim reformy społeczne ${ }^{26}$. Punktem zwrotnym w historii współczesnej Ukrainy były lata 2000-2004, kiedy prezydent Rosji zaostrzył politykę wobec tego kraju. Polegało to na wprowadzaniu restrykcyjnych warunków korzystania $\mathrm{z}$ rurociągu gazowego, a także wspieraniu rozprzestrzeniania się rosyjskich koncernów w kraju ${ }^{27}$. Miało to swoją przyczynę po części w nieudolności polityki zagranicznej UE, która sama ukierunkowała Ukrainę w stronę Rosji.

${ }^{21}$ Ibidem, s. 14.

${ }^{22}$ Kelemen 2015.

${ }^{23}$ Turczyński 2013, s. 63.

${ }^{24}$ Leszczyński 2014, s. 54.

${ }^{25}$ Turczyński 2013, s. 63.

${ }^{26}$ Ibidem, s. 64.

${ }^{27}$ Ibidem, s. 66 . 
Zauważalne to było w momencie, gdy UE obiecała $800 \mathrm{mln}$ euro pożyczki na odbudowę reaktora atomowego, $\mathrm{z}$ czego się nie wywiązano ${ }^{28}$. Ponadto ważnym czynnikiem rozbijającym proces integracji z UE stanowił jej brak reakcji na zaistniały kryzys polityczny na początku XXI wieku ${ }^{29}$.

Podstawową przyczyną kryzysu na Ukrainie była błędna polityka ówczesnego prezydenta Wiktora Janukowycza, a także szczyt Partnerstwa Wschodniego UE w Wilnie w dniach 28-29 listopada 2013 roku, kiedy to wcześniej wspomniany polityk odrzucił przygotowaną do podpisania umowę stowarzyszeniową z UE ${ }^{30}$. Faktyczny kryzys, który odbił się echem w całej Europie, uległ eskalacji dopiero w roku 2014 ${ }^{31}$, dokładniej w momencie ucieczki Wiktora Janukowycza do Rosji, ustalenia i przeprowadzenia wyborów prezydenc$\mathrm{kich}^{32}$. Nowym prezydentem w maju 2014 roku został Petro Poroshenko, który próbował załagodzić sytuację po EuroMajdanie z lat 2013/2014, zwalczyć korupcję poprzedniego rządu, a także zbliżyć się do zachodu ${ }^{33}$. W marcu 2014 roku Federacja Rosyjska, wykorzystując kryzys polityczny na Ukrainie, czy też rozpoczynającą się wojnę na wschodzie kraju, zauważyła szansę na przywłaszczenie sobie części terytorium, tj. Półwyspu Krymskiego ${ }^{34}$. Wydarzenia te rozpoczęly się zaraz po ucieczce Wiktora Janukowycza z kraju, wtedy też język rosyjski został ustawowo zakazany jako drugi oficjalnie obowiązujący ${ }^{35}$. Spowodowało to niezadowolenie regionów rosyjskojęzycznych, a także w konsekwencji zajęcie kluczowych budynków w mieście Symferopol przez prorosyjskich działaczy w dniach 27-28 lutego ${ }^{36}$. Następnie już 1 marca parlament rosyjski zatwierdził użycie wojsk na terytorium Ukrainy, pod pretekstem obrony praw mniejszości rosyjskiej, co oczywiście było nielegalne $\mathrm{w}$ świetle prawa międzynarodowego ${ }^{37}$. Aneksja została przeprowadzona niezwłocznie po ogłoszeniu wyników referendum, w którym około 97\% dopuszczonych do głosowania opowiedziało się za odłączeniem od Ukrainy, a w konsekwencji, w późniejszym okresie, próbę przystąpienia do Federacji Rosyjskiej $^{38}$.

${ }^{28}$ Ibidem.

${ }^{29}$ Ibidem.

${ }^{30}$ Stępniewski 2016, s. 44.

${ }^{31}$ Marxsen 2014, s. 367.

${ }^{32}$ Stępniewski 2016, s. 44.

${ }^{33}$ Morelli 2016, s. 3.

${ }^{34}$ Ibidem, 18.

${ }^{35}$ BBC News 2014.

${ }^{36}$ Ibidem.

${ }^{37}$ Walker i Salem 2014.

${ }^{38}$ BBC News 2014. 
UE nie pozostawiła tej sytuacji bez odzewu, jednakże polityka zastosowana wobec Rosji nie była zbyt skuteczna. Polegała ona na uchwaleniu sankcji bezpośrednio uderzających w rosyjski sektor przemysłowy, a także finanso$w^{39}$. Zastosowanie ich wobec państwa najeźdźcy było trafne, jednakże niezbyt skuteczne, gdyż niezbyt rygorystyczne. Pokazało to słabość UE wobec tak wielkiego gracza na arenie międzynarodowej, jakim jest Federacja Rosyjska, mimo iż zaangażowanych w to było większość państw członkowskich, m.in. Niemcy, które uderzyły bezpośrednio w przemysł energetyczny ograniczając import, czy też Polska wraz z całą Grupą Wyszehradzkąa ${ }^{40}$ W odpowiedzi na to Federacja Rosyjska w stopniu znacznym zmniejszyła import żywności, co spowodowało załamanie i złagodzenie polityki sankcji głównie wśród członków Grupy Wyszehradzkiej, gdyż straciła ona najbardziej dochodowy rynek zbytu swoich produktów ${ }^{41}$. Obserwując takie zachowanie Rosji, można wyprowadzić wniosek, że Rosja nie napotkała żadnej przeszkody ze strony UE w trakcie aneksji Krymu, a przy tym już od samego początku pokazała swoją dominującą rolę w Europie i silną opozycję dla UE.

W 2015 roku przedstawiciele najważniejszych państw UE, a także stron konfliktu po raz kolejny postanowili spotkać się, aby załagodzić sytuację i osiągnąć konsensus. Kanclerz Niemiec Angela Merkel, prezydent Francji François Hollande, prezydent Rosji Wladimir Putin, a także prezydent Ukrainy Petro Poroszenko debatowali nad rozwiązaniem sprawy wschodniej Ukrainy w Mińsku ${ }^{42}$. Można zatem wysunąć wniosek, że jedynym działaniem UE, które w konsekwencji dawało szansę zakończenia konfliktu, była mediacja $\mathrm{z}$ jego stronami. Do najważniejszych założeń paktu należały przede wszystkim wycofanie całej broni ciężkiej z okręgu wschodniego, monitorowanie przestrzegania zawieszenia broni, ochrona niesienia pomocy humanitarnej, czy też wprowadzenie nowej konstytucji państwa z końcem 2015 roku $^{43}$. Jednakże analizując przebieg negocjacji i konkluzje, trzeba zastanowić się czy negatywne skutki nie przewyższają korzyści. Warto zatem wspomnieć o kwestiach interpretacji, mianowicie zwiększenie zobowiązań ze strony ukraińskiej spowodowało uzależnienie wielu decyzji od zgody separatystów, co było klęską ze strony mediatorów, do których należała m.in. UE ${ }^{44}$.

\footnotetext{
${ }^{39}$ Kotyzová, Bahenský i Kufčák 2015, s. 7.

${ }^{40}$ Ibidem, s. 9 .

${ }^{41}$ Ibidem.

${ }^{42}$ Morelli 2016, s. 20.

${ }^{43}$ Ibidem, s. 21.

${ }^{44}$ Kardaś i Konończuk 2015.
} 
Sedno sytuacji na Ukrainie stanowiła kwestia legalności aneksji Krymu. Podstawowym argumentem użytym przez Federację Rosyjską była ochrona mniejszości rosyjskiej zamieszkującej tamte tereny. Kolejnym jest zaś przyjęcie ówczesnego prezydenta Wiktora Janukowycza, a także jego zgoda na wkroczenie wojsk na terytorium Ukrainy jako jedyny sposób utrzymania kontroli nad krajem ${ }^{45}$. Warto zaznaczyć, że jest to punkt widzenia Federacji Rosyjskiej. Nasuwa się zatem jednoznaczny wniosek, że działania Rosji były nielegalne $\mathrm{z}$ punktu widzenia prawa międzynarodowego, jednakże UE w obawie o pogorszenie relacji, a także z braku środków, którymi skutecznie mogłaby zatrzymać terytorialne zapędy Rosji, nie powzięła żadnych radykalnych działań ${ }^{46}$. Konkludując, zwrócić należy uwagę na uzależnienie UE od polityki softpower. Przekłada się to na brak przygotowania do zderzenia $\mathrm{z}$ radyklaną polityką Rosji ${ }^{47}$, co $\mathrm{w}$ konsekwencji powoduje zmniejszenie, a dalej zanik wiarygodności wspólnoty jako partnera na arenie międzynarodowej.

Podsumowując, na podstawie obserwacji można stwierdzić, że polityka zagraniczna i bezpieczeństwa UE wobec państw członkowskich, a także państw ościennych jest nieudolna. Doświadczenie w postaci kryzysu migracyjnego czy też aneksji Krymu przez Federację Rosyjską pokazuje, że UE nie jest obojętna na sytuację, która bezpośrednio zagraża bezpieczeństwu państw członkowskich. Nieudolność w stosowaniu środków bezpieczeństwa czy prowadzeniu polityki zagranicznej może jednak w przyszłości stać się czynnikiem dezintegrującym państwa Europy. Zaryzykować można również stwierdzenie, że polityka bezpieczeństwa UE jest jedynie pozorna, działa na zasadzie pustego zapewniania obywateli Europy o jej skuteczności. Konkludując, warto zastanowić się nad tym, czy takie traktowanie poważnych sytuacji w Europie nie jest cichym przyzwoleniem na nie.

\footnotetext{
${ }^{45}$ Geiß 2015, s. 432.

${ }^{46}$ Zięba 2015, s. 12.

${ }^{47}$ Godzimirski, Puka i Stormowska 2015, s. 7.
} 


\section{EFFECTIVENESS OF EU FOREIGN AND SECURITY POLICIES: AN ATTEMPT AT ASSESSMENT}

\section{Summary}

The article discusses the stages in which the Common Foreign and Security Policy developed and reviews all instruments which over the years regulated its functioning. What is more, the author advances an unequivocal hypothesis presuming ineffectuality of that ideology-policy, or in other words the pretence of security ensured to EU member states. Some of the examples to support that hypothesis include the conflict in eastern Ukraine, which began in 2013, and the migration crisis which has since then affected most member states.

\section{Bibliografia}

Bigo D., Carrera S., Guild E., Guittet E.-P., Jeandesboz J., Mitsilegas V., Ragazzi F., Scherrer A. 2015, The UE and its Counter-Terrorism Policies after the Paris Attacks, CEPS Paper in Liberty and Security in Europe 84, s. 4-7.

Boniecka M. 2015, Cele, zasady i struktura wspólnej polityki zagranicznej i bezpieczeństwa Unii Europejskiej - próba oceny po zmianach w Traktacie lizbońskim [online]. Koło Naukowe Prawa Cywilnego Usus Iuris [dostęp: 2018-02-12]. Dostępny w Internecie: $<$ http://zeszyt.amu.edu.pl/uploads/zeszyt/numery/Nr\%205/BONIECKA\%20streszczenie.pdf>, s. 47-52.

Ciamaga L., Latoszek E., Michałowska-Gorywoda K., Oręziak L., Teichmann E. 2002, Unia Europejska. Warszawa.

Folkerts-Landau D. 2015, Influx of refugees: An opportunity for German [online]. Standpunkt Deutschalnd [dostęp: 2017-12-06]. Dostępny w Internecie: <https://www.dbresearch.com/ PROD/DBR_INTERNET_EN-PROD/PROD0000000000365616/Influx_of_refugees\%3A_ An_opportunity_for_Germany.pdf $>$, s. 15-16.

Geiß R. 2015, Russia's Annexation of Crimea: The Mills of International Law Grind Slowly but They Do Grind, International Law Studies, 91 (425), s. 432-437.

Godzimirski J.M., Puka L., Stormowska M. 2015, Czy UE wyciągnęła wnioski z kryzysu na Ukrainie. Zmiany w rządzeniu w obszarze bezpieczeństwa, energii i migracji. Polski Instytut Spraw Międzynarodowych, Warszawa, s. 7-13.

Hungary As a Country of Aylum, Observations of restrictive legal measures and subsequent practice implemented between July 2015 and March 2016, 2016 [online]. UNHCR [dostęp: 2017-10-02]. Dostępny w Internecie: <http://users.ecs.soton.ac.uk/harnad/Hungary/2016 UNCHR.pdf $>$, s. 8-13.

Huysmans J. 2006, The Politics of Insecurity. Fear, migration and asylum in the UE, London, s. 63-85.

Juhász A., Hunyadi B., Zgut E. 2015, Focus on Hungary: Refugees, Asylum and Migration [online]. Political Capital [dostęp: 2017-10-08]. Dostępny w Internecie: <https://www. boell.de/sites/default/files/2015-focus-on-hungary_refugees_asylum_migration.pdf >.

Kardaś Sz., Konończuk W. 2015, Mińsk 2 - kruchy rozejm zamiast trwałego pokoju [online]. Ośrodek Studiów Wschodnich [dostęp: 2017-10-25]. Dostępny w Internecie: <https://www. osw.waw.pl/pl/publikacje/analizy/2015-02-12/minsk-2-kruchy-rozejm-zamiast-trwalegopokoju $>$. 
Keleman D.R. 2015, Europe's Hungary Problem, Viktor Orban Flouts the Union. Foreign Affairs [dostęp: 2017-11-02]. Dostępny w Internecie: <https://www.foreignaffairs.com/ articles/europe/2015-09-20/europes-hungary-problems>.

Keren D. 2015, The Paris Black Friday 13/11/2015 Attacks - What do we know? What Should we do? [online]. International Institute of Counter-Terrorism [dostęp: 2017-11-01]. Dostępny w Interncie: <https://www.ict.org.il/UserFiles/ICT-The-Black-Friday-Paris-AttacksNov15.pdf >, 2-3.

Kotyzová V., Bahenský V., Kufč́k J. 2015, Cooperation of CE countries in response to situation in Russian Federation and in Ukraine [online]. International Affairs for Prague Student Summit [dostęp: 2017-10-05]. Dostępny w Internecie: <https://www.amo.cz/ wp-content/uploads/2016/01/PSS-Cooperation-of-CE-countries-in-response-to-situationin-Russian-Federation-and-in-Ukraine-V4-.pdf $>$, s. 7-8.

Leszczyński P.A. 2014, Bezpieczeństwo narodowe Ukrainy w kontekście jej podstaw konstytucyjnych i położenia geopolitycznego - węzłowe zagadnienia, Zeszyty Naukowe Uniwersytetu Przyrodniczo-Humanistycznego w Siedlcach 103, s. 53-55.

Marxsen Ch., 2016, The Crimea Crisis From An international Law Perspective, Kyiv-Mohyla Law and Politics Journal 2, s. 367-368.

Morelli V.L., 2016, Ukraine: Current Issues and U.S. Policy [online]. Congressional Research Service [dostęp: 2017-10-23]. Dostępny w Internecie: <https://fas.org/sgp/crs/row/RL33460. pdf $>$, s. 1-4, 19-32.

O'Nions H., 2014, Asylum - A right denied. A Critical Analysis of European Asylum Policy [online]. Ashgate Publishing Company [dostęp: 2017-11-24]. Dostępny w Internecie: $<$ https://extranet.uj.edu.pl/eds/ebookviewer/ebook/,DanaInfo=eds.a.ebscohost.com+ZTA wMHh3d19fNjc5NTA1X19BTg2?sid=c9fa0ffe-461b-42ce-8a03-73b2827771d6@sessionmgr $4006 \&$ vid $=0 \&$ format $=$ EK\&lpid $=\mathrm{i} 5 \&$ rid $=0 \#>$, s. 522-525.

Potyrała A. 2015, W poszukiwaniu solidarności. Unia Europejska wobec kryzysu migracyjnego 2015, Przegląd Polityczny 4, s. 37-42.

Stępniowski T. 2016, Konflikt zbrojny na Ukrainie i negocjacje pokojowe w Mińsku, Studia Europejskie 3, s. 43-59.

Traktat o Funkcjonowaniu Unii Europejskiej, Art. 78, (w:) L. Krzyżanowski (red.), Prawo Unii Europejskiej, Bielsko-Biała.

Turczyński P. 2007, Wspólna Polityka Zagraniczna i Bezpieczeństwa UE, Wrocław.

Ukraine crisis: Timeline 2014 [online]. BBC News [dostęp: 2018-02-11]. Dostępny w Internecie: <http://www.bbc.com/news/world-middle-east-26248275>.

Walker Sh., Salem H. 2014, Russian parliamentapprovestroopdeployment in Ukraine [online]. The Guardian [dostęp: 2018-02-11]. Dostępny w Internecie: <https://www.theguardian. com/world/2014/mar/02/russia-parliament-approves-military-ukraine-vladimir-putin>.

Wijaszka J. 1995, Wspólna polityka zagraniczna i bezpieczeństwa UE. Współpraca polityczna z państwami stowarzyszonymi Europy Środkowej, Polski instytut spraw międzynarodowych, Warszawa, s. 21.

Willa R. 2012, Wspólna Polityka Zagraniczna i Bezpieczeństwa Unii Europejskiej w świetle Traktatu z Lizbony, K. Marchlewska-Patyk, A. Wedeł-Domaradzka (red.), Studia i analizy Europejskie 1 (9), s. 19-35.

Wysoki przedstawiciel do spraw zagranicznych i polityki bezpieczeństwa / Europejska Służba Działań Zewnętrznych, 2009 [online]. Sekretariat Ogólny Rady Unii Europejskiej [dostęp: 2017-11-12]. Dostępny w Internecie: <http://www.consilium.europa.eu/media/31124/ background-highrepresentative_pl.pdf $>$.

Zięba R. 2015, Ukraina jako przedmiot rywalizacji między Zachodem a Rosją [online]. Wydział Nauk Politycznych i Dziennikarstwa UAM [dostęp: 2018-02-03]. Dostępny w Internecie: $<$ http://ssp.amu.edu.pl/wp-content/uploads/2016/02/ssp-2015-3-005.pdf>, s. 5-26. 